DARKO GAVRILOVIĆ, Associate Professor

University of Novi Sad

LJUBIŠA DESPOTOVIĆ, Full Professor

UDK 94:323(497.1)"198/199"

Belgrade, Megatrend University

316.48(497.11)"198/199"

\title{
YUGOSLAVIA - BEGINNING OF THE END
}

\begin{abstract}
On the basis of the different literature, article comments the political forces that were active in the period prior to the disolution of the Socialist Yugoslavia. Authors payed a emphasis to the CIA's reports in late eighties, which showed a disolution process from the specific point of view showing disputes on the Yugoslavia's interrior scene.
\end{abstract}

Key words: Yugoslavia, Communist Party, socialism, nationalism, economy, religion, conflict

\section{Weakness of the Communist period}

Although the Communist regime in SFRJ was considerably less severe than other Communist regimes in Eastern Europe, especially after 1965, there nevertheless remain serious grievances against it. These include grievances related to the expropriation of property, forced resettlement (including the expulsion of much of the ethnic German population), arrest and imprisonment of political opponents, and abrogation of political rights and public expression. Probably the largest scale act of repression was the imprisonment of pro-Soviet Communists after the break with the Soviet Union in $1948 .{ }^{1}$

The communist regime in Yugoslavia, despite the lack of democracy no matter how paradoxical it might sound - fostered some aspects of civil society which previously did not exist, such as the separation of the church from the state, civil marriage, equal legal rights for women, national minorities, and so forth. ${ }^{2}$ Nevertheless, despite several opportunities for democratization, the main fabric of the state remained political - the rule of the communist party and the armed forces being represented by the JNA.

\footnotetext{
${ }^{1}$ See Ivo Banac, With Stalin Against Tito: Cominformist Splits in Yugoslav Communism, Ithaca, Cornell University Press, 1989.

${ }^{2}$ Blofeld E. S., Balcanizzazione dell' Europa o africanizzazione dei Balcani, in Conflittualita Balcanica. Inegrazione Europea. Ricerche interdisciplinary, 1993, pp. 44-51.
} 
The 1968-72 periods was in fact the time when the transformation of Yugoslavia in a modern industrial country was fully undertaken, marking the beginning of prosperity and the definitive overcoming of poverty and illiteracy. And yet, Yugoslav society, which had endured the sacrifices necessary to achieve such a goal, found itself unpreperated to face the new challenges that the complexity and articulation of a developed society posed to it. In particular, during those years Yugoslavia missed a fundamental cultural step in the path towards growth and stability: the transformation of a society which continued (and wanted to continue) to represent and imagine itself as a dual society (communist versus anticommunists, anti-fascists versus fascists, us versus them, etc.) into a society which, on the contrary, manifested itself as a plural society. What Yugoslav communism (like Soviet communism) was not capable of understanding was that the transformations induced by the process of modernization it promoted would inevitably create plurality of interests which could not always nor exclusively be contained within a rigid single party system. ${ }^{3}$

Despite this, the rhetoric of the struggle of the anti-fascist partisans continued to be the lynchpin in the legitimacy of the Communist Party, and in the creation of an identity shared by the population. Thus, the Party's claim to the monopoly of political power and to the existence of a common Yugoslav state had its roots in wartime. However, such experience was couched in a rigidly dualistic, if not outright Manichean, language. Although in the Sixties historians had started to reinterpret the history of the Second World War, trying to shed a light on the complexity and multiplicity of the subjects involved, official and educational historiography continued to propose a simplistic (and dualistic) scheme which involved „revolutionaries“ (the partisans) against „counter-revolutionaries“ (ranging from Croat Ustashias and Serbian Chetniks to local Quislings and the bourgeois government in exile), obviously reserving to the former not only political legitimacy, but also morality and the monopoly of positive virtues. ${ }^{4}$

What was missing between 1968 and 1972 was the ability to replace the idea of a shared historical memory as an integrating and stabilizing factor for the Yugoslav regime with a new sense of belonging based on a plural Yugoslav identity, that is, the ability to make "Yugoslavness" both the encompassing whole and the bond holding together individual southern Slav characters. However, a political and cultural action of this nature would have struck at the heart of the nationalist vision still shared by the middle ranking party cadres and society at large. Well, in all former Yugoslav republics, the period between the 1960's and 1970's was crucial for the intellectual elaboration of the political bases of the dissolution of Yugoslavia at the end of the 1980's.

\footnotetext{
${ }^{3}$ Privitera Francesco, Between Yugoslavism and Separatism. The Role of The Intellectuals in Yugoslavia, The Balkans, National Identities in a Historical Perspective, Ravenna 1998, p. 132.

${ }^{4}$ See W. Hoepken, Guerra, memoria ed educazitione in una societa ,divisa": il caso della Jugoslavia, in Passato e presente, Vol. 16, No. 43, 1998.
} 
Even beside that, we must say that regardless of the fact that Yugoslav socialism was more humane than the similar systems in force in other Eastern European countries, it did not recognize nor approve the different needs of certain ethno - national groups or their different positions within the Federation or at international level, as was the case with the issue of the Macedonian minority in the neighboring countries.

Also it is important to mention the influence of the economic development on dissolution of Yugoslavia. Well, the most important law of this period was the Law of Associated Labor, adopted in November 1976. It introduced the principle of discussion and arrangement into the economy. All the relatively independent economic units were organized in the Basic Organization of Associated Labor, in which the workers, in accordance with self-management principles, decided what and how much they would produce and how the money they earned would be spent. This arrangement replaced the market economy: the price of the final product would be as calculated and arranged, not according to principles of supply and demand. Republics and communes, who became responsible for their own development, were forced into extensive investments. The system promoted production of technologically less demanding products, allowing for a work force with minimal education: it provided for full employment, but its effects were deleterious. Old technology and poor quality products and performance meant that failure was inevitable. ${ }^{5}$ The catastrophe that threatened the Yugoslav economy was postponed by international loans. Yugoslavia became one of the world's most indebted countries. ${ }^{6}$ Money was spent on housing, infrastructure and investment in undeveloped regions (Kosovo, Bosnia and Herzegovina, Macedonia, and Montenegro) instead of on production investments that would realize the money to repay the loans.

Despite this, people appreciated the rise in living standards (private and social) and the absence of unemployment. This situation lasted until the end of the 1970s when, because of the world energy crisis, the flow of foreign capital stopped. By then, the situation was catastrophic: the state's external debt was US\$20 billion; inflation and unemployment were rising; productivity and living standards were declining. ${ }^{7}$ In the shops there were fewer and fewer articles for general consumption.

Tito's death in 1980 spelled the beginning of the end for Yugoslavia. The Yugoslav leadership tried to continue the internal and external policies of his regime under the slogan 'Also after Tito - Tito'. Retaining the old system in Yugoslavia was impossible, however, because the state now had no leader who could, with his charisma, paper over regional differences in the state and in interethnic relations. After Tito's death, Yugoslavia found itself in a process of dissolution

${ }^{5}$ S. Estrin, Self-Management: Economic Theory and Yugoslav Practice, Cambridge 1983, pp. 81-126; John Lampe, Yugoslavia as History cit., pp. 315-316.

${ }^{6}$ B. McFarlane, Yugoslavia: Politics, Economics, and Society, London 1988; H. Lydall, Yugoslavia in Crisis, Oxford 1989.

${ }^{7}$ J. R. Lampe, Yugoslavia as History. Twice there was a country, Cambridge 1996, p. 315-316. 
which ended in the conflagration of the 1990s. Help from the West initially postponed debt crises, but eventually exacerbated the situation. Fundamental economic change was needed to help the economy out of crisis, but the communist old guard was not ready for that. Political crisis exacerbated the deepening economic crisis; and interethnic relations deteriorated, beginning with worsening Serb-Albanian relations. This was the prelude to the bloody demise of Yugoslavia in the 1990s.

\section{Beginning of the End}

The one of the main reasons for the crisis of the Yugoslavia in the eighties, which led to its dissolution in 1991, was indeed the selection of party cadres and therefore of the heads of public institutions. The bureaucratic elephantiasis, corruption, personal careerism and, and multinational contexts, the „feudalization“" of local elites completely paralyzed Yugoslavian (and Eastern Europe, too) communist system which already blocked face to the new economic and social challenges of global modernization. Also, it should be mention that Yugoslavia became an alliance of republic's oligarchies that produced the political deadlock which followed the death of Tito, in 1980. In terms of the mass media, a curiously mixed process of fake and genuine diversity got underway. As the republican Communist elites became overtly competitive and critical of each other and of the federation, the media were allowed to become critical too. The media were manipulated to enhance the republican elites' authority, usually by appealing to national sentiments. However, astute journalists were able to create space for genuinely independent work by exploiting new divisions among the authorities. The whole process was further complicated because politics had specific features in each republic and autonomous region. Indeed, what was say able or printable in one unit of the federation could incur a prison sentence in another. ${ }^{8}$ In 1989, new legislation was enacted allowing the foundation of private companies, including media enterprises, which added oil to fire and resulted in an open media war between the republics. It definitely split the already shattered Yugoslav information space along ethno-national fault-lines.

The turning point for the breakdown of Yugoslavia occurred in 1989, as the process of disintegration of the Soviet Union and of the Eastern - European countries under its domination. With its complex ethnic composition, Yugoslavia started to disintegrate as the system and the Federation fell apart. The Communist party lost its dominant position in the political life of the country, and multi party systems started to be adopted in each of the former republics. During the transition from the "dictatorship of the proletariat" towards a democratic civil society new, young, a few educated political party leaders emerged among the intellectuals (mainly University professors, writers and activists), besides majority, of „transformed“ previous communist politicians.

${ }^{8}$ Thompson M., Forging War: The Media in Serbia, Croatia and Bosnia-Herzegovina, Article 19, International Centre Against Censorship, May 1994., p. 7. 
Thus, the political parties were a major ex communist driving force in the process of the constitution of civil society, as carriers of the paradigm of political pluralisation: free elections, rule of law, a market economy, freedom of speech, and so forth. ${ }^{9}$ Generally speaking, their demands corresponded to the experiences and traditions of Western Europe.

But is it so in the Yugoslav space?

Three religions, Orthodox Christianity, Catholicism, and Islam, historically played major roles in shaping different ethno-national identities. The frontier-line between Eastern and Western Christianity roughly cut the space into two, with the massive presence of the Muslim element in Bosnia and Herzegovina and Sandzak, in Kosovo and in Macedonia. Religious consciousness, of course, preceded modern ethno-national self-identification, but the border-lines drawn between religious communities (often but not always coinciding with linguistic groups) in the Balkan space predetermined to a great extent the contours of the different Southern Slav ethno-national communities that were shaped later, even when their modern identities had been secularized. Serbian Orthodox Church marked the political space of "Greater Serbia“ by carrying across presumed „Serb lands" the earthly remnants of „Emperor" Lazar, the prince who was killed by the Turks at the battle of Kosovo back in 1389. The battle itself became in the 20. century the very important myth of the Serb expansionist project and was appropriate by the Karadjordjević dynasty. Also, it became an integral part of chetnik ideology during the WWII and recently the battle cry of resuscitated Serb nationalism. A number of priests took an active part in the wars in Croatia and Bosnia whose declared aim was to ,gather all the Serbs in one state" and priests blessed publicly known war criminals. On the other side, The Roman Catholic hierarchy in Croatia had unsettled problems with the Communist regime dating back to WWII and the unambiguous relationship Zagreb's Archbishop Stepinac with the ustasha puppet-state. After the War, Stepinac was arrested and judged and sentenced to prison, where he died. After that, he was promoted into a symbol of resistance to Communist rule. For Croat nationalists, especially from the Diaspora, he became a martyr. When the Communist regime was finally on the verge of collapse and when the first free elections were scheduled in Slovenia and Croatia, The Roman Catholic Church put all its moral weight and logistical support behind anti-Communit groups and parties who were, in the same time, nationalists. The Christian message of peace was definitely not heard by those catholic priests who in Mostar bless usurped and stolen property, or who by their silence condone ethnic cleansing and the systematic destruction of Orthodox churches all over Croatia and in the part of Bosnia and

${ }^{9}$ Mojanoski C., Tranzicijata i partiskiot system vo Republika Makedonija, in Dijalog, Skopje 1995, No. 10, 9.121. 
Herzegovina, held by Croat forces. ${ }^{10}$ In Bosnia and Sandzak, Islam was infallible part of Bosnjak's nationalism. Alija Izetbegovic, the President of the internationally recognized Republic of Bosnia and Herzegovina, started his political carrier as an Islamic thinker. He expressed ideas along the lines of neo-fundamentalist thinkers such as the Pakistani Mawdudi and the Egyptian Qutb. In his book Islam Between East and West in 1983, he advocated the establishment of an Islamic society, with its own laws, where Muslims are the majority and in which non'Muslims would be treated as a ,protected minority”, not as full citizens.

Even if the religion played its part in the breakdown of Yugoslavia, once more, we should not forget the fatal role of the Communist party. Also, in spite of their claims, even in the late 80 's, the Communists did not succeed in ,equalizing" the conditions of life in the cities and countryside. The Communists did not succeed in building up an urban - rural continuum with a balanced distribution of institutions and services between town and village. The tidal wave of modernization spreads in concentric circles, invading one zone after another, which creates obvious inequalities perceived by local elites as deliberate discrimination, and exploitation by the central state and its bureaucracy. The underdevelopment of backward area may then become the main theme of separatist ethno-national discourse, as occurred in Kosovo. Exactly such a perception gave birth to contemporary Slovene and Croat separatism. In both cases, local elites and counter-elites were convinced that they would fare much better if they were in command of the modernization process. In both federations the benefits of economic progress were unevenly distributed, not only between zones inhabited by different ethno-national groups, but also within ethnically homogeneous territories, and finally everybody has some reason to feel frustrated.

We should have on mind that, also, Communist modernization produces a social drama and a crisis of social identities but the same phenomena may be observed in many other countries included those in which the Communists had little influence. The peasantry was the main victim of the process of distorted modernization in this zone. The mass of half - peasants/half - workers, together with marginalized suburban and urban dwellers, became the physical force of violent change in the late 80's. Middle class intellectuals and their ethno nationalist discourses in Yugoslavia rationalized violent change. ${ }^{11}$

That is the moment when the „national“ middle class turns to the people and when the production of nationalist ideology initiates ethno-national political mobilization. But it should be mentioned that ethno-nationalist ideologies had conquered the mass media much before the final collapse of the Yugoslavia federation. While at beginning timid and indirect, dealing with the preservation of national heritage, monuments and culture, nationalist propaganda became more

\footnotetext{
${ }^{10}$ Iveković Ivan, Ethnic and Regional Conflicts in Yugoslavia and Transcaucasia - A Political Economy of Contemporary Ethnonational Mobilization, Longo Editore, Ravenna 2000, p. 137.

${ }^{11}$ Ibid, p. 14.
} 
and more „affirmative“, disseminating ethnic fear and hatred. Challenged from all sides, significant segments of the nomenclatures, whose legitimacy was rapidly eroding, opened the media in their own republics-regions to nationalist counter-elites. Although, nationalism was, „from the outset a „bourgeois“ phenomenon linked to the emerging capitalist order $^{12}$, it appears now that ,socialist" state-command economies were equally "successful“" in the production of the same phenomenon. Not dissimilar from their „bourgeois“ counterparts, Communist bureaucrats used nationalism to legitimate their political projects and to manipulate the masses.

In spite of the efforts of the Yugoslav federal government to radically reform the economic system, political developments went from bad to worse. Milosevic's clique had discovered the usefulness of street politics. Also, by the CIA documents, Milošević „established himself as champion of Serbian nationalism and authoritarian rule ... He has provoked a greater tensions with liberal north, and he has lost significant support among Yugoslavia's southern republics ... In his home republic of Serbia, Milošević is facing increased criticism from liberal youth, intellectuals and workers. Milošević will probably try to defend himself by responding aggressively; attacking opponents, sponsoring new demonstrations, and provoking new confrontations with the northern republics of Slovenia and Croatia...". ${ }^{13}$ After having leadership of Kosovo and Vojvodina, Milosevic's followers targeted Slovenia, whose authorities were accused of supporting „Albanian separatists" and of enmity against Serbia. Milošević supporters even scheduled a „Meeting of Truth“ in Ljubljana, the capital city of Slovenia, but the Slovenian government forcefully prevented it from taking place. In retaliation, Serb authorities imposed a total boycott on any trade or financial transactions with Slovenia, while the property of Slovenian companies on the territories of Serbia and Montenegro was practically confiscated. In turn, Slovenia suspended the payment of its dues to the federal Fund for Underdeveloped. ${ }^{14}$ Contrary to the situation in Serbia, in March 1990, CIA's report recorded „secessionist sentiment seemed to be growing as Slovenia headed toward the first round of assembly and presidency elections on 8 April. The campaign for April assembly elections in Croatia was increasingly dominated by the ultra nationalistic Croatian Democ-

${ }^{12}$ Nairn T., Nationalism and the Uneven Geography of Development, in Held, D. et al (eds.) State and Society, Oxford, Basil Blackwell in association with The Open University, 1983, p. 198.

${ }^{13}$ CIA internet documents: Directorate of Intelligence, 10. 1. 1990, Yugoslavia: Conservative Leader Under Pressure, p. 1. www.foia. cia. gov

${ }^{14}$ We do not have access to historical documents about the last phase of the dissolution of Yugoslavia, but on the basis of several clues it is possible to argue that Kucan and Milošević probably reached agreement on 21 January 1991 on the possible separation of Slovenia. Through private talks with people close to the Slovenian government at that time, we know that the price for the separation of Slovenia was a public declaration by Kucan on the right of Serbs to live in a country of their own. This declaration was made on TV by Kučan on the day following that meeting, thus legitimizing Serbian separatism. In an interview with the BBC, Milošević spoke again about this agreement. F. Privitera, ibid., p. 151. 
ratic Union, whose growing support was pushing the other parties toward more nationalistic position..." “15

As CIA reports supposed, the political situation became more serious, because, in Slovenia and Croatia were political spectrum ,ranging from Social Democracy on the left to Christian Democracy - and even fascism - on the right ... The ability of both republics to transcend the narrow chauvinism of the pre World War II era ... In Serbia, the predominant post - Communist ideology will be attuned to the intense nationalist and religious tradition..."16

During the spring and summer situation in Croatia become from bad to worse. Intelligent Service notice that in August „Croatian leader Tudjman has accused Serbia of fomenting the disturbances to bring down his government. A republic spokesman said Croatia will defend itself and restore state authority over the entire republic. The risk of violence tomorrow is high. If Federal forces and Croatian police units are on duty in the same areas, they could clash. Any fighting could easily spill over into ethnically mixed Bosnia and other regions and ignite a wider conflict..." ${ }^{\text {"17 }}$ which was happened next year. During the summer of 1990, „street demonstrations and reports of military maneuvers showed that tension between Serbs and Croats in Croatia is increasing: a referendum on Serbian autonomy tomorrow could trigger civil conflict and topple the Croatian nationalist government of Franjo Tudjman. ${ }^{18}$

The new political forces now in power in Slovenia, Croatia and Serbia opposed all federal initiatives, taking part in several meeting between January and March 1991 in which their representatives remained deadlocked into their own position. Through the control of the mass media in each Republic it was easy for the local leadership to keep public opinion under pressure, gradually destroying the democratic spaces that had just created. The Yugoslav federation had already collapsed, but few people were able to understand this before 25 June 1991, when Slovenia and Croatia announced their secession with the tacit approval of Serbia. ${ }^{19}$

Yugoslav economic problems begin earlier. It should be notice that in 1989, huge economic problems shake Yugoslav market and political scene. CIA's documents notice that "Yugoslavia's economic problems are exacerbating ethic tensions and threatening Belgrade with its second change of government in less than a year ... Debate over Marković's (Ante Marković was Yugoslavian premier) fate and his reform policies has split increasingly along republic lines,

${ }^{15}$ CIA internet documents: Yugoslavia; Key Points, Secret, March 1990.www.foia. cia. gov

${ }^{16}$ CIA internet documents: Yugoslavia Transformed, p. 7. www.foia. cia. gov

${ }^{17}$ CIA internet documents: Yugoslavia: Civil Conflict Likely in Croatia, Top Secret, 18. August 1990, p. 5. www.foia. cia. gov

${ }^{18}$ Ibid.

${ }^{19}$ Since 1991, relationships between Tudjman and Milošević have been very ambiguous. In that period, the two leaders met 48 times. F. Privitera, ibid., p. 151. 
reflecting regional economic interests and Serbia's attempts to exploit difficulties. The southern republics, led by Serbia, have charged that Markovic, a Croat, and his northern allies are insensitive to the disproportionate impact of inflation and reform on the less developed south. The more market oriented northern republics of Croatia and Slovenia support Marković's charge that effort to curb inflation are being blocked by Serb politicians more interested in toppling the government than working together. They cite Serbia's plan to raise a 1 billion „patriotic loan“ for its own development as evidence. “20 Between October 1990 and February 1991, first business banks and then the National Banks of different federal republics issued about 4 billion Deutsche Marks of fictious ,grey dinars“ with which they plundered federal hard currency reserves. They used the system known in monetary theory as credit multiplication, creating „primary money” without the knowledge of or control by the Central Bank of Yugoslavia. ${ }^{21}$

The fact that the federal state had collapsed, and with it its central political authority, meant that the bodies ultimately defining civil and political order disappeared. The (emerging) proto-states were aspiring nation-states, not yet recognized by the international community. Accountability for law and order still rested on the state of Yugoslavia; when it disappeared a vacuum appeared, bringing with it legal void and anomie. The republics were unaccountable with respect to the international community, and thus in a sense free of responsibility. In a context where a monopoly of the legitimate use of force is no longer vested in a „legal“ state, violence is no longer constrained. It could be said that an ,anything goes" situation arose, in which different leaderships, buttressed by the support they had managed to get from their majority nations, tried to maximize their immediate gains irrespective of the long-term consequences for themselves, their citizens and the country at large. ${ }^{22}$

All these events helped people to compare themselves to others. Almost, it was enough in itself to initiate political violence. Economic stagnation and crisis created a social drama, and provoked a crisis of individual and collective identities. This crisis set up the stage for ethnic confrontation, but real violence erupted only when politically manipulated ethnic communities were organized and set into motion.

The Central Intelligence Service's report about key points on situation in Yugoslavia is probably the best way to describe what was happened in those days

${ }^{20}$ CIA internet documents; Yugoslavia - Economy Threatens Government, Special Analysis, 14. September 1989, p. 14. www.foia. cia. gov

${ }^{21}$ The National Bank of Serbia with the complicity of Serbian business banks, siphoned in this manner DEM 3.1 bilion (21.7 bilion dinars), the National Bank of Montenegro DEM 289 million, the National Bank of Croatia DEM 242 milion, and the National Bank of Slovenia DEM 143 milion, while Macedonian and Bosnian National Banks issued much smaller amounts of grey dinars. Dinkić, M., Ekonomija destrukcije: velika pljačka naroda, Belgrade, Video nedeljnik, 1995, pp. 68-9.

${ }^{22}$ Vejvoda Ivan, Yugoslavia 1945-91: from Decentralization Without Democracy to Dissolution, in Dyker D. A., and Vejovda I, (eds.) Yugoslavia and After: A Study of Fragmentation, Despair and Rebirth, London and New York, Longman, 1996, p. 20. 
"The demise of Yugoslav federation continued to move inexorably forward as Slovenia and Croatia announced they were seeking „disassociation“ from Yugoslavia and ethnic Serbs in Croatia and Bosnia declared their desire to live in one country with their Serbian brothers in other republics. The federal army and Croatian military almost came to blows in late January and again in early March ... Croatian claims that Serbia is deliberately trying to provoke a confrontation suggests that the potential for conflict remains high. Prime minister Marković's economic reform program has been totally discredited ... Slovenian and Croatian leaders lobbied hard for international recognition during visits to key West European states, while the Serbian press stopped up attacks against the West, particularly US diplomats in Belgrade.“23

Finally, the wars took place in Yugoslavia during 1991-1995 periods, and they were not inevitable. Alternative political solutions to war could have been found by local leaders. Even after the war, in 1995-1999 periods the same leaders of 1991 were facing the same problems as in 1991, after years of war, and without the chance of playing the trump card of armed confrontation again: the economic crisis in countries weakened by the war, the inability to strengthen democracy and civil society. The conduct of the wars of succession shocked many, as the wars produced the greatest numbers of deaths, refugees and incidents of violent abuse seen in Europe since 1945. In most cases, justification for atrocities was offered by nationalist programs which sought control of territory, and in many cases establishing control of territory involved killing, intimidating and forcibly moving local residents on the basis of ethnicity. At the same time, more or less rigid control of public information led to situation in which even now many people say that they are not well informed about events which took place during the wars. Feeling of guilt, victimization and resentment are widespread, and are very likely intensified by the failure to produce reliable accounts. ${ }^{24}$

Darko Gavrilović, Ljubiša Despotović

\section{JUGOSLAVIJA - POČETAK KRAJA}

\section{Rezime}

Socijalistička Federativna Republika Jugoslavija je okončala svoje postojanje ne samo zbog nesposobnosti Saveza komunista Jugoslavije već i zato što je „rezervoar“ političke želje da se Jugoslavija održi kao jedna zemlja počeo da presušuje krajem 1980-ih. Na samom početku devedesetih godina federacija je prestala da postoji, a Jugoslavija se kao država raspala. Slom Jugoslavije je prouzrokovan političkim, ekonomskim, konfesionalnim i etničkim faktorima. Čak i uspešne ekonomske reforme nisu uspele da održe Jugoslaviju. Najjače kohezivne snage postale su suprotnost: najjače rasturajuće snage. One su bile na delu u Sloveniji, Hrvatskoj i Srbiji. Možemo ih opisati kao mešavinu nacionalnog ponosa, lokalnih ekonomskih težnji kao i istorijski suprotstavljenih verskih i kulturnih aspiracija. Ni Jugoslovenska narodna armija niti Savez komunista nisu bili u moći da održe federaciju u celosti, jer su i sami bili zarobljenici međuetničkih konflikata.

${ }^{23}$ CIA internet documents: Yugoslavia, Key Points, Secret, 8. March 1991. www.foia. cia. gov

${ }^{24}$ Gordy Eric D., What does it mean to break with the past?, Facing the Past, Facing the Future; University of Bologna 2005, p. 90. 